\title{
Papillary thyroid cancer nodal metastases mimicking a slow-flow lymphatic malformation
}

\author{
Munira Ally, Neeral Patel, Kunwar Bhatia, Zaid Awad
}

Otolaryngology, Charing Cross Hospital, London, UK

\section{Correspondence to Miss Munira Ally, munira.ally@nhs.net}

Accepted 12 June 2018
D Check for updates

(c) Author(s) (or their employer(s)) . No commercial re-use. See rights and permissions. Published by BMJ.

To cite: Ally M, Patel N, Bhatia K, et al. BMJ Case Rep Published Online First: [please include Day Month Year]. doi:10.1136/bcr-2018 225043

\section{DESCRIPTION}

A 28-year-old Caucasian man was referred to the head and neck clinic with a 2-year history of a right-sided neck lump, which had started to cause discomfort. Physical examination revealed two discrete non-tender neck masses in the region of the right sternocleidomastoid muscle, with no bruit or palpable pulse.

CT demonstrated multiple right-sided thinwalled cystic lesions within the upper to lower jugular chain and posterior triangle (levels II-V) forming a multiloculated cystic lesion measuring $10 \mathrm{~cm}$ in craniocaudal dimension. Ultrasound assessment suggested a multiloculated cystic mass with thin walls and no intralesional flow, extending along the posterior margin of the right sternocleidomastoid muscle, posterolateral to the right internal jugular vein. The thyroid and major salivary glands appeared unremarkable. Fine-needle aspiration cytology (FNAC) proved inconclusive. The abnormality was presumed to be a slow-flow lymphatic malformation; however, injection sclerotherapy did not result in resolution, confirmed on an MRI scan performed 6 months later (figure 1). FNAC was not repeated due to the working diagnosis. Following multidisciplinary team discussion, a comprehensive selective right-sided neck dissection of levels

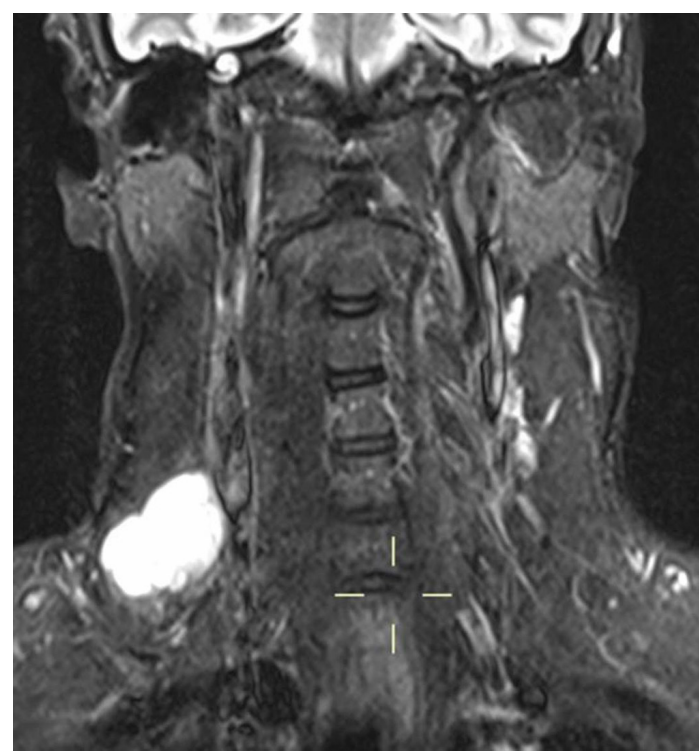

Figure 1 T2 fat-saturated MRI study of the neck that demonstrates persistence of the right-sided cystic lesion despite injection sclerotherapy. There is subtle low signal at the base of the lesion, which was initially thought to be debris. In retrospect, this is likely to reflect mural nodularity of one of the cysts.

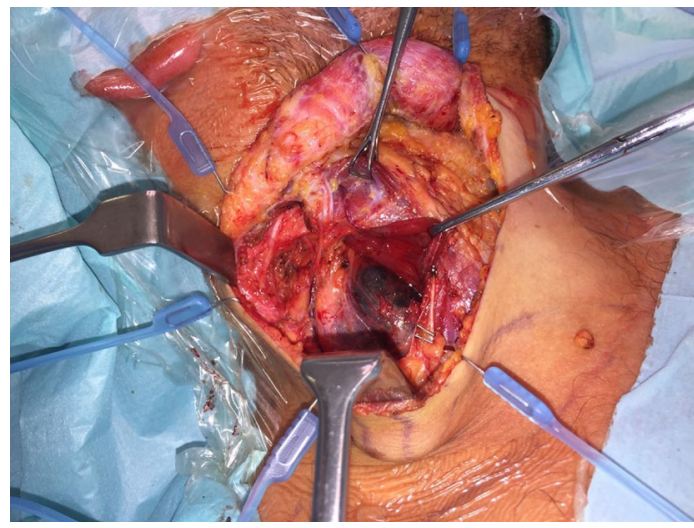

Figure 2 Intraoperatively, the mass was found to be cystic and dark in colour.

II-V was performed using a low lateral skin crease incision at the level of the cricoid cartilage yielding 15 markedly cystic lymph nodes. All anatomical structures were identified and preserved. The neck masses were found to be cystic and dark in colour intraoperatively (figure 2). Histological analysis revealed the nodes to be positive for thyroid transcription factor 1 , indicative of papillary thyroid cancer (PTC) metastases. The patient underwent total thyroidectomy extending the same incision to the anterior neck, which demonstrated microscopic PTC. As the neck dissection was complete, there was no need to reopen the lateral neck. Radio-iodine ablation treatment was then administered. The patient remains disease free at 6 months' clinical and biochemical follow-up.

A cystic lateral neck mass can be a diagnostic challenge for radiologists and ear, nose and throat surgeons. Differential diagnoses include a metastatic node, branchial cleft cyst, lymphovascular malformation, necrotic node post-suppurative lymphadenitis and cystic neurogenic tumour. In adults, cystic metastatic nodes from head and neck cancer are well recognised, especially from squamous cell carcinoma and papillary carcinoma. The presence of a thickened wall and/or mural nodularity in a cystic mass should raise the possibility of malignancy, although this cannot be relied on, as metastatic nodes can be thin walled and completely cystic. ${ }^{1}$ Therefore, any cystic neck mass in the lateral neck in an adult should undergo US-guided FNAC for confirmation. Unfortunately in this case, the FNAC was inconclusive. That there were multiple cystic nodes was not appreciated before surgery as the nodes were abutting one another, simulating a multiloculated cystic lesion. 
Patients with PTC usually present with a palpable or incidentally detected impalpable thyroid nodule; however, they may present with cervical lymphadenopathy. ${ }^{23}$ Rarely, the primary tumour may be microscopic and radiologically occult. Definitive treatment for PTC with nodal metastasis comprises total

\section{Learning points}

- Malignant lesions including metastases should always be considered in adults with cystic lesions of the neck.

- Papillary thyroid cancer metastases can present as markedly cystic mass or masses in the mid to lower neck, and the primary cancer can be microscopic or occult.

- A comprehensive compartmental lymph node dissection with histological diagnosis is required in cases where fine needle aspiration proves inconclusive rather than a simple lymph node excision. thyroidectomy with selective neck dissection and radioactive iodine, followed by long-term hormonal suppression. PTC has an excellent prognosis with over 90\% 5-year survival for early stage disease.

Contributors This manuscript was coauthored by MA, NP, KB and ZA.

Funding The authors have not declared a specific grant for this research from any funding agency in the public, commercial or not-for-profit sectors.

Competing interests None declared.

Patient consent Obtained.

Provenance and peer review Not commissioned; externally peer reviewed.

\section{REFERENCES}

1 Yehuda M, Schechter ME, Abu-Ghanem N, et al. The incidence of malignancy in clinically benign cystic lesions of the lateral neck: our experience and proposed diagnostic algorithm. Eur Arch Otorhinolaryngol 2018;275:767-73.

2 Lloyd RV, Buehler D, Khanafshar E. Papillary thyroid carcinoma variants. Head Neck Pat ho/2011;5:51-6.

3 Shi L, Song H, Zhu H, et al. Pattern, predictors, and recurrence of cervical lymph node metastases in papillary thyroid cancer. Contemp Oncol 2013;17:504-9.

Copyright 2018 BMJ Publishing Group. All rights reserved. For permission to reuse any of this content visit

http://group.bmj.com/group/rights-licensing/permissions.

BMJ Case Report Fellows may re-use this article for personal use and teaching without any further permission.

Become a Fellow of BMJ Case Reports today and you can:

- Submit as many cases as you like

Enjoy fast sympathetic peer review and rapid publication of accepted articles

- Access all the published articles

- Re-use any of the published material for personal use and teaching without further permission

For information on Institutional Fellowships contact consortiasales@bmjgroup.com

Visit casereports.bmj.com for more articles like this and to become a Fellow 